\title{
A bisulfite treatment and PCR-free global DNA methylation detection method using electrochemical enzymatic signal engagement
}

Ripon Bhattacharjee, ${ }^{\mathrm{a}, \mathrm{b}}$ Sofia Moriam, ${ }^{\mathrm{a}, \mathrm{b}}$ Nam-Trung Nguyen, ${ }^{\mathrm{b}}$ and Muhammad J. A. Shiddiky ${ }^{\mathrm{a}, \mathrm{b} *}$

a School of Environment and Science, Griffith University, Nathan Campus, Nathan, QLD 4111, Australia

${ }^{\mathrm{b}}$ Queensland Micro- and Nanotechnology Centre (QMNC), Griffith University, Nathan Campus, Nathan, QLD 4111, Australia

$\dagger$ Electronic supplementary information (ESI) available. 


\begin{abstract}
In this paper we report on a bisulfite treatment and PCR amplification-free method for sensitive and selective quantifying of global DNA methylation. Our method utilises a three-step strategy that involves $(i)$ initial isolation and denaturation of global DNA using the standard isolation protocol and direct adsorption onto a bare gold electrode via gold-DNA affinity interaction, (ii) selective interrogation of methylation sites in adsorbed DNA via methylation-specific 5mC antibody, and (iii) subsequent signal enhancement using an electrochemical-enzymatic redox cycling reaction. In the redox cycling reaction, glucose oxidase $\left(\mathrm{GO}_{\mathrm{x}}\right)$ is used as an enzyme label, glucose as a substrate and ruthenium complex as a redox mediator. We initially investigated the enzymatic properties of $\mathrm{GO}_{\mathrm{x}}$ by varying glucose and ruthenium concentration to delineate the redox cyclic mechanism of our assay. Because of the fast electron transfer by ruthenium $(\mathrm{Ru})$ complex and intrinsic signal amplification from $\mathrm{GO}_{\mathrm{x}}$ label, this method could detect as low as 5\% methylation level in $50 \mathrm{ng}$ of total DNA input. Moreover, the use of methylation-specific $5 \mathrm{mC}$ antibody conjugated $\mathrm{GO}_{\mathrm{x}}$ makes this assay relatively highly selective for DNA methylation analysis. The data obtained from the electrochemical response for different levels of methylation showed excellent interassay reproducibility of RSD (relative standard deviation) $<5 \%$ for $n=3$. We believe that this inexpensive, rapid, and sensitive assay will find high relevance as an alternative method for DNA methylation analysis both in research and clinical platforms.
\end{abstract}

Key words: Bisulfite free, Glucose oxidase, Enzymatic redox cyclic reaction, global DNA, Electrochemistry. 


\section{Introduction}

Development of a reliable methodology for epigenetic biomarker detection is a key demanding factor in accurate diagnosis and prognosis of the cancer progression (Portela and Esteller 2010). DNA methylation is a well-known epigenetic change that could be occurred via hypermethylation or hypomethylation (Ehrlich 2002). Increased oncogene expression, activating transcription and altering the genomic stability often refer to hypomethylation, and it is observed in metastatic tissues and primary tumors. To profile DNA methylation, generally bisulfite treatment is used to convert all the DNA without changing the epigenetic mark, which could allow subsequent analysis of DNA bases by well stablished molecular biology techniques, such as direct sequencing (Paul and Clark 1996), pyrosequencing (Tost and Gut 2007), methylation-sensitive melting curve analysis (MS-MCA) (Worm et al. 2001) and methylation-sensitive high-resolution melting (MS-HRM) (Wojdacz and Dobrovic 2007) etc. Despite high reliability of these methods, their inability to detect 5-methylcytosine $(5 \mathrm{mC})$ oxidation products ( $\mathrm{Wu}$ and Zhang 2017), incomplete conversion of cytosine to uracil (Genereux et al. 2008; Grunau et al. 2001; Rein et al. 1997), primer design (Li 2007; Thomassin et al. 1999), and biased PCR amplification (Luo and Preuss 2003; Warnecke et al. 1997; Wojdacz et al. 2014) make the overall detection method more challenging and time-consuming.

To avoid these complications, numerous bisulfite free methods for DNA methylation analysis have been proposed. Efforts have also been directed towards the development of platforms that are rapid, cost effective and involve simple operation to extend their application to routine clinical testing (Kurinomaru and Kurita 2017; Zhang et al. 2015). Among these techniques, enzyme-linked immunosorbent assay (ELISA) is used to quickly assess global DNA methylation using $100 \mathrm{ng}$ to $2.0 \mu \mathrm{g}$ of total DNA. However, high variability of this assay is only suitable for the rough estimation of DNA methylation (Kurdyukov and Bullock 2016). Another common approach of DNA methylation detection is the use of affinity capture agents 
such as methyl binding domain (MBD) proteins or antibodies raised against 5-methylcytosine, which have also gained much interests (Haque et al. 2017a; Krejcova et al. 2017). While MBD proteins have high affinity towards methylated $\mathrm{CpG}$ region in double-stranded DNA (dsDNA) (Yin et al. 2014), they tend to be biased towards CpG dense sequences and unable to discern methylation status of individual CpGs. In contrast, apart from binding with single-stranded DNA (ssDNA), the 5mC antibodies can capture low $\mathrm{CpG}$ density regions with efficiencies comparable to that of high $\mathrm{CpG}$ density regions. Moreover, the $5 \mathrm{mC}$ antibody can specifically recognise and bind to the methylated site without the prior treatment of restriction enzymes (Haque et al. 2017a). As these strategies do not require amplification, it affects the sensitivity and applicability for the low amounts of methylated DNA in clinical samples (Dai et al. 2012). Thus, development of a highly sensitive method that can produce enhanced signal from a low input of DNA is still an urgent demand.

In recent years, much attention has been focused on the development of electrochemistry based assay due to field portability, intrinsic simplicity, high sensitivity, short analysis time, cost-effectiveness, and compatibility with the miniaturization (Bhattacharjee et al. 2018a; Drummond et al. 2003; Hossain et al. 2017; Labib et al. 2016; Wang et al. 2013; Yu et al. 2016a; Yu et al. 2016b; Yu et al. 2016c). In this continuation, several PCR amplification free electrochemical assays have also been developed (Dai et al. 2012; Daneshpour et al. 2016; Povedano et al. 2018; Wang et al. 2013; Wee et al. 2015). Most of these assays were developed based on either nanomaterials (NMs) or enzyme to improve the sensitivity and selectivity. Due to their large surface area and biocompatibility, Numerous studies have been reported that utilizes a wide variety of nanomaterials of different morphologies, such as, nanosheets, nanospheres, nanowires etc that increase the performance for detection of DNA methylation. However, the unstable nature and loss of enzyme activity during immobilization process of the NMs affects the thermal and chemical stability, sensitivity, and reproducibility of the biosensor. 
(Daneshpour et al. 2016; Yin et al. 2014; Zhang et al. 2007). Beside NMs, various enzymes e.g. alkaline phosphatase (AP), horseradish peroxidase (HRP), glucose oxidase $\left(\mathrm{GO}_{\mathrm{x}}\right)$ etc are also considered most popular groups of tracer labels. These enzymes have been immobilized on various materials to enhance the enzymatic catalytic signals (Akanda and Ju 2017; delle Noci et al. 2008; Haque et al. 2017a; Kaatz et al. 2012; Lai et al. 2009; Singh et al. 2013; Zhang et al. 2017). Another advantage of using the enzymes is direct electron transfer between the electrode and enzyme label, which could improve the signal in a biosensor. However, a large electron-hopping distance between the electrode and the redox centre of the enzyme label could create few challenges for efficient electron transfer in biosensor (Chen et al. 2007). To overcome these limitations, mediated electron transfer can be achieved using a redox mediator that conveys electrons between the electrode and the redox center present in solution. This process is known as electrochemical enzymatic (EN) redox cycling reaction (Singh et al. 2013). In this reaction, electroactive molecules such as $\mathrm{Ru}$ complexes $\left(\left[\mathrm{Ru}\left(\mathrm{NH}_{3}\right)_{6}\right]^{3+}\right)$ undergo a fast outer-sphere electron-transfer reaction at the electrodes as well as electron-transfer reactions with redox enzymes (Chen and McCreery 1996).

Herein, we introduced a simple and sensitive assay for the detection of global DNA methylation using EN redox cycling reaction. In our assay, extracted genomic DNA was denatured at $95{ }^{\circ} \mathrm{C}$ to obtain ssDNA which was directly adsorbed onto an unmodified screenprinted gold electrodes (SPGE) followed by the immune-recognition of the methylated groups using $\mathrm{GO}_{\mathrm{x}}$ conjugated $5 \mathrm{mC}$ antibody $\left(5 \mathrm{mC}-\mathrm{GO}_{\mathrm{x}}\right)$. In the presence of the glucose and ruthenium complex, the electrode generates enhanced chronocoulometric $(\mathrm{CC})$ responses via EN redox cycling. The catalytic response is directly proportional to the amount of the surface-bound $5 \mathrm{mC}-\mathrm{GO}_{\mathrm{x}}$ (i.e., the amount of the methylation level in the surface-bound ssDNA). The method has been tested in analyzing methylation level in two ovarian cancer cell lines and one normal cell line using CC readout. Due to the following unique features, this proof-of-concept method 
can be used as an alternative to existing conventional methods for global DNA methylation detection with better sensitivity and selectivity, greater simplicity, lower cost and faster analysis time. These features includes- (i) sensitive - as it uses fast-enzymatic redox reaction, (ii) selective - as this assay employs $5 \mathrm{mC}$ antibody which is highly specific for the methyl groups, (iii) simple - as it avoids the use of conventional sensor fabrications steps, (iv) bisulfitefree -it avoids chemical treatment of DNA with sodium bisulfite to convert DNA modifications into base changes, and $(v)$ amplification-free - it avoids the use of polymerase chain reaction based amplification procedures to increase DNA yield.

\section{Experimental}

\subsection{Reagents and chemicals}

Antibody- $\mathrm{GO}_{\mathrm{x}}$ conjugation kit (ab102887) was purchased from Abcam, Inc. (Cambridge, MA, USA). $\mathrm{GO}_{\mathrm{x}}$-conjugated $5 \mathrm{mC}$ antibody were prepared in phosphate buffer $(50 \mathrm{mM}, \mathrm{pH} 7.4)$ according to the manufacturer's procedure. Hexaammineruthenium (III) chloride $\left(\mathrm{RuHe}_{\mathrm{x}}\right)$, glucose, bovine-serum albumin (BSA), and all reagents for buffer solutions were obtained from Sigma-Aldrich, Co. and New England Biolab (NEB). Tris buffer comprised $50 \mathrm{mM}$ tris(hydroxymethyl)aminomethane ( $\mathrm{pH}$ 8.0). Phosphate- buffered saline (PBS, $\mathrm{pH}$ 7.4) comprised $10 \mathrm{mM}$ phosphate, $0.138 \mathrm{M} \mathrm{NaCl}$, and $2.7 \mathrm{mM} \mathrm{KCl}$.

\subsection{Isolation and purification of genomic DNA}

Two ovarian cancer cell lines (SKOV 3, OVCAR 3) and one normal cell line (MeT-5A) were purchased from American Type Culture Collection (ATCC), USA. A blood and cell culture DNA mini kit (Qiagen, Hilden, Germany) was used to extract and purify the DNA from these 
cell lines. Jurkat genomic (100\% methylated) DNA was purchased from New England BioLab. Whole genomic amplified DNA (WGA) was prepared by following the protocol of REPLI-g whole genome amplification mini kit (Qiagen, Hilden, Germany) and purified following the protocol DNeasy Blood \& Tissue Kits (Qiagen).

\subsection{Electrochemical detection of global DNA methylation}

$20 \mu \mathrm{L}$ of isolated genomic DNA were denatured at $95{ }^{\circ} \mathrm{C}$ followed by the dilution with $5 \mathrm{X}$ saline sodium citrate (SSC) buffer and $1 \%$ BSA to obtain $10 \mathrm{ng} / \mu \mathrm{L}$ of ssDNA. Then, $5 \mu \mathrm{L}$ of denatured ssDNA samples were dropped onto a screen-printed gold electrode (SPGE) (WE: gold (diameter: $4 \mathrm{~mm}$ ), CE (platinum) and RE (silver) purchased from Dropsens, Spain) surface and allowed to adsorb for $10 \mathrm{~min} .1 \%$ BSA was used to block the uncovered electrode surface area with target DNA to minimize the non-specific adsorption of biological molecules. $5 \mu \mathrm{L}$ of $\mathrm{GO}_{\mathrm{x}}-5 \mathrm{mC}$ antibody $(20 \mathrm{ng} / \mu \mathrm{L})$ was added onto the gold electrode surface and allowed to incubate for $30 \mathrm{~min}$ at room temperature with gentle shaking (unless otherwise stated) to facilitate the binding of the $\mathrm{GO}_{\mathrm{x}}-5 \mathrm{mC}$ antibody with the designated methylcytosine site of ssDNA. After the incubation, the electrode was washed with $10 \mathrm{mM}$ PBS (pH 7.4) to remove loosely bounded or unbounded $\mathrm{GO}_{\mathrm{x}}-5 \mathrm{mC}$ antibody. A CH1040C potentiostat $(\mathrm{CH}$ Instruments, TX, USA) was used to perform the electrochemical measurements. The CC responses were recorded in the presence of $60 \mu \mathrm{L}$ of glucose substrate solution $(2 \mathrm{mM})$ mixed with $10 \mu \mathrm{M}$ $\mathrm{RuHe}_{\mathrm{x}}$ in Tris buffer ( $\mathrm{pH}$ 8.0) solution onto the gold electrode surface with a potential $+50 \mathrm{mV}$ for $100 \mathrm{~s}$. At least three replicates were measured at room temperature for each standard/sample and all data were subtracted from the background data.

\subsection{Determination of the Surface Area of the Electrodes}


The effective working area of the electrodes was calculated by measuring the peak current obtained as a function of scan rate under cyclic voltammetric conditions for the one-electron reduction of $\left[\mathrm{Fe}(\mathrm{CN})_{6}\right]^{3-}[2.0 \mathrm{mM}$ in PBS $(0.5 \mathrm{M} \mathrm{KCl})]$ and by using the Randles-Sevcik equation (equation 1) (Allen J. Bard 2001; Shiddiky et al. 2010),

$$
i_{p}=\left(2.69 \times 10^{5}\right) n^{3 / 2} A D^{1 / 2} C v^{1 / 2}
$$

where, $i_{p}$ is the peak current $(\mathrm{A}), \mathrm{n}$ is the number of electrons transferred $\left(\mathrm{Fe}^{3+} \rightarrow \mathrm{Fe}^{2+}\right.$, $\mathrm{n}=1), A$ is the active area of the electrode $\left(\mathrm{cm}^{2}\right), D$ is the diffusion coefficient of $\left[\mathrm{Fe}(\mathrm{CN})_{6}\right]^{3-}$ taken to be $\left.7.60 \times 10-5 \mathrm{~cm}^{2} \mathrm{~s}^{-1}\right), C$ is the concentration $\left(\mathrm{mol} \mathrm{cm}{ }^{-3}\right), v$ is the scan rate $\left(\mathrm{Vs}^{-1}\right)$.

\subsection{Glucose Oxidase Kinetics}

The Steady-state kinetics of glucose and $\mathrm{RuHe}_{\mathrm{x}}$ were analysed using the Michaelis-Menten and Lineweaver-Burk models. The steady-state kinetic experiments were performed using 100 ng of $\mathrm{GO}_{\mathrm{x}}$ for both glucose substrate and $\mathrm{Ru}\left(\mathrm{NH}_{3}\right)_{6}{ }^{3+}$ mediator by varying the concentrations of (A) Glucose $(0.01-5.0 \mathrm{mM})$ and $(\mathrm{B}) \mathrm{RuHe}_{\mathrm{x}}(0.01-100.0 \mu \mathrm{M})$ with fixed amounts of (A) $\mathrm{Ru}_{\mathrm{x}}(10 \mu \mathrm{M})$ and (B) glucose $(2 \mathrm{mM})$, respectively. To obtain the corresponding electrochemical signals from these samples, chronoamperometric responses were taken at $60 \mathrm{~s}$ by applying a fixed potential of $+50 \mathrm{mV}$.

Kinetic parameters were estimated based on the simplified Michaelis-Menten and Line weaver-Burk equations (equation 2) (Lehninger 2005; Masud et al. 2017; Tanaka et al. 2018),

$$
\frac{1}{V}=\frac{K_{m}}{V_{\max }} \frac{1}{[\mathrm{~S}]}+\frac{K_{m}}{V_{\max }}
$$

In this equation, $V$ is the rate of conversion, $V_{\max }$ is the maximum rate of conversion, [S] is the substrate concentration, and $K_{m}$ is the Michaelis constant which is equivalent to the 
substrate concentration at which the rate of conversion is half of $V_{\max } . K_{m}$ denotes the affinity of the enzyme for the substrate.

\section{Results \& Discussion}

\subsection{Assay principle}

In this work, methylation specific antibody $(5 \mathrm{mC})$ was used to specifically recognize methyl group in genomic DNA. To read the methylation level, 5mC was conjugated with glucoseoxidase $\left(5 \mathrm{mC}-\mathrm{GO}_{\mathrm{x}}\right)$, and electrochemical-enzymatic redox cycle was performed. Briefly, double-strand genomic DNA were denatured to generate ssDNA and allowed to adsorb on SPGE. After DNA adsorption, $5 \mathrm{mC}-\mathrm{GO}_{\mathrm{x}}$ was added onto the electrode surface to complete the immunorecognition process. Here, $5 \mathrm{mC}$ is specific to methylated site of the ssDNA and $5 \mathrm{mC}$ $\mathrm{GO}_{\mathrm{x}}$ only attaches to the methylated DNA on the electrodes. In the presence of $\mathrm{GO}_{\mathrm{x}}$, $\mathrm{Ru}\left(\mathrm{NH}_{3}\right)_{6}{ }^{3+}\left(\mathrm{Ru}_{\mathrm{x}}{ }^{3+}\right)$ was reduced to $\mathrm{Ru}\left(\mathrm{NH}_{3}\right)_{6}{ }^{2+}\left(\mathrm{Ru}_{\mathrm{x}}{ }^{2+}\right)$ and glucose was oxidised to gluconic acid. During this process, $\mathrm{Ru}_{\mathrm{x}}{ }^{2+}$ oxidised back to $\mathrm{Ru}_{\mathrm{x}}{ }^{3+}$ and completed the redox cycle. Therefore, increased chronocoulometric response in electrochemical readout is directly proportional to the amount of $\mathrm{GO}_{\mathrm{x}}$, which is successively proportional to the methylation level in the sample. The overall reaction process is known as ping-pong mechanism and shown in equations 3-5 (Gorski 2001; Singh et al. 2013; delle Noci et al. 2008). The working principle of this assay is depicted in Fig. 1.

$$
\begin{aligned}
& \text { Glucose }+\mathrm{GO}_{\mathrm{x}(\mathrm{Ox})} \longrightarrow \mathrm{GO}_{\mathrm{x}(\mathrm{Red})}+\text { Gluconic acid } \\
& 2 \mathrm{Ru}_{\mathrm{x}}{ }^{3+}+\mathrm{GO}_{\mathrm{x}(\mathrm{Red})} \longrightarrow \mathrm{GO}_{\mathrm{x}(\mathrm{Ox})}+2 \mathrm{Ru}_{\mathrm{x}}{ }^{2+}+2 \mathrm{H}^{+} \\
& 2 \mathrm{Ru}_{\mathrm{x}}{ }^{2+}
\end{aligned}
$$

\subsection{Assay optimization}


To get the optimum performance of the assay, several experimental conditions (i.e the amount of target DNA, $\mathrm{pH}$, incubation time etc.) need to be optimised. Previously, we have optimised the major adsorption parameters such as adsorption time, $\mathrm{pH}$ of the solution and amount of input DNA to obtain the maximum electrochemical responses between methylated and unmethylated DNA targets (Haque et al. 2017b; Koo et al. 2015; Sina et al. 2014). In the current assay, we have adopted all these optimised parameters and unless otherwise stated, we directly adsorbed 50 ng of target DNA (diluted in $5 \mathrm{X}$ SSC buffer, $\mathrm{pH} 7.4$ ) onto the unmodified SPGE for $10 \mathrm{~min}$. Conventional BSA blocking was also used to prevent the non-specific adsorption of target DNA onto the gold electrode surface. As can be seen in Fig. S1, the difference between the responses at the BSA-blocked and-unblocked electrodes is about $22 \mu \mathrm{C}-\mathrm{cm}^{-2}$, which is almost 1.15-times higher than that of the electrodes with 1\% BSA blocking. Notable, the total charge from $50 \mathrm{ng}$ of WGA at the electrode without BSA blocking is significantly higher which indicates the non-specific adsorption of the biomolecules onto the electrode surface.

In the case of enzymatic redox cyclic reaction, $\mathrm{Ru}_{\mathrm{x}}{ }^{3+}$ undergo fast outer-sphere electron transfer reaction at electrodes which create lot of background noise (Akanda et al. 2012; Singh et al. 2013; Tanimoto and Ichimura 2013). Thus, it is important to optimize the concentration of glucose substrate solution and $\mathrm{Ru}_{\mathrm{x}}{ }^{3+}$ solution. To obtain the maximum signal to noise ratio, electrooxidation of $\mathrm{Ru}_{\mathrm{x}}{ }^{2+}$, the enzymatic reduction of $\mathrm{Ru}_{\mathrm{x}}{ }^{3+}$ and enzymatic oxidation of glucose by $\mathrm{GO}_{\mathrm{x}}$ should be faster. However, without $\mathrm{GO}_{\mathrm{x}}$ in the system, the direct electrooxidation of glucose and direct electron-transfer between glucose to $\mathrm{Ru}_{\mathrm{x}}{ }^{3+}$ should be slower to maintain a low background noise. These requirements were investigated prior to use our assay for detecting methylation level. We used Tris buffer as the electrolyte for the electrochemical readout step ( $\mathrm{pH} 8.0$ was selected from a previously published work (Singh et al. 2013)) and compared the electrochemical responses in the presence or absence of glucose oxidase in the system. Fig. S1 shows the comparison of chronocoulometric responses obtained from Tris 
buffer ( $\mathrm{pH}$ 8.0), $2.0 \mathrm{mM}$ Glucose (in tris), $2.0 \mathrm{mM}$ Glucose and $10 \mu \mathrm{M} \mathrm{RuHe} \mathrm{x}_{\mathrm{x}}$ (in tris) in the absence and presence of $\mathrm{GO}_{\mathrm{x}}$. In this assay, we applied $+50 \mathrm{mV}$ of potential to measure the electrochemical readout which is much higher than the formal potential of $\mathrm{Ru}_{\mathrm{x}}{ }^{3+} / \mathrm{Ru}_{\mathrm{x}}{ }^{2+}$ (ca.$150 \mathrm{mV}$ ) to faster the electro-oxidation process in the system. This is due to the $\mathrm{CC}$ charge that generate during $\mathrm{Ru}_{\mathrm{x}}{ }^{3+} / \mathrm{Ru}_{\mathrm{x}}{ }^{2+}$ redox cycling is controlled only by mass transfer of $\mathrm{Ru}_{\mathrm{x}}{ }^{2+}$ to the electrode not by the kinetics of $\mathrm{Ru}_{\mathrm{x}}{ }^{2+}$ electrooxidation (Gorski 2001; Singh et al. 2013). However, we found that the surface response on Tris buffer and glucose substrate solution without $\mathrm{Ru}_{\mathrm{x}}$ and $\mathrm{GO}_{\mathrm{x}}$ shown almost similar response $\left(20 \mu \mathrm{C} / \mathrm{cm}^{2}\right.$ vs $21 \mu \mathrm{C} / \mathrm{cm}^{2}$, intercept at $\mathrm{Y}$ axis) but obvious improved (charge density of about $35 \mu \mathrm{C} / \mathrm{cm}^{2}$ ) response was observed when $\mathrm{RuHe}_{\mathrm{x}}$ was added in the solution (blue line). Once $\mathrm{GO}_{\mathrm{x}}$ present in the redox system, the overall enzymatic reaction improved and the response in the $\mathrm{CC}$ readout was also improved (charge density of about $250 \mu \mathrm{C} / \mathrm{cm}^{2}$ ). These results signify the slower electrochemical oxidation and electron transfer in glucose and between glucose and $\mathrm{Ru}_{\mathrm{x}}{ }^{3+}$ when $\mathrm{GO}_{\mathrm{x}}$ is not present. However, oxidation reaction improved the enzymatic redox reaction thus shown a high CC response in the Fig. S2.

The concentration of glucose and $\mathrm{RuHe}_{\mathrm{x}}$ solutions are also need to be optimized to achieve the optimal catalytic performances. We constructed Michaelis-Menten model and Lineweaver-Burk model experiments by changing the glucose substrate concentration between $0.01 \mathrm{nM}$ and $5.0 \mathrm{mM}$, and $\mathrm{RuHe}_{\mathrm{x}}$ concentration between $0.01 \mu \mathrm{M}$ and $100.0 \mu \mathrm{M}$, respectively. In Fig. 2(A), maximum current density $\left(I_{\max }\right)$ before saturation for glucose was obtained at $2.0 \mathrm{mM}$ concentration $\left(\mathrm{RuHe}_{\mathrm{x}} 10.0 \mu \mathrm{M}, \mathrm{GO}_{\mathrm{x}} 100.0 \mathrm{ng} / \mu \mathrm{L}\right)$, on the otherhand, $\mathrm{RuHe}_{\mathrm{x}}$ showed the $I_{\max }$ for the our EN reaction at $10 \mu \mathrm{M}$ (Glucose $2.0 \mathrm{mM}, \mathrm{GO}_{\mathrm{x}} 100.0 \mathrm{ng} / \mu \mathrm{L}$ ) in Fig. 2(B). We further calculated the $V_{\max }$ and $K_{m}$ for both glucose and ruthenium complex from Lineweaver-Burk (shown inset in Fig. 2). The measured $V_{\max }$ and $K_{m}$ values for glucose were $2.04 \mu \mathrm{M}^{-1}$ and $0.27 \mathrm{mM}$, respectively which were much higher than $\mathrm{Ru}_{\mathrm{x}}\left(V_{\max }=1.72 \mu \mathrm{M}^{-}\right.$ 
${ }^{1}$ and $\left.K_{m}=0.22 \mu \mathrm{M}\right)$. These findings suggested that, the oxidation of glucose by $\mathrm{GO}_{\mathrm{x}}$ enzyme was faster than the $\mathrm{Ru}_{\mathrm{x}}{ }^{3+} / \mathrm{Ru}_{\mathrm{x}}{ }^{2+}$ transformation. From these experiments, we selected glucose concentration as $2.0 \mathrm{mM}$ and $\mathrm{RuHe}_{\mathrm{x}}$ concentration $10.0 \mu \mathrm{M}$ for our entire experiment. Then we optimized the $\mathrm{GO}_{\mathrm{x}}$ concentration and incubation period for the assay. Fig. S3(A) shows that the charge density increased with the $\mathrm{GO}_{\mathrm{x}}$ concentration from $10.0 \mathrm{ng}$ to $100.0 \mathrm{ng}$. After 100 ng to $1.0 \mu \mathrm{g}$ of $\mathrm{GO}_{\mathrm{x}}$ concentration, the charge response did not change much, thus we have selected $100.0 \mathrm{ng}$ of $\mathrm{GO}_{\mathrm{x}}$ for our assay. The incubation period for antibody was selected 30 minutes as the charge density started to be stable after 30 minutes Fig. S3(B).

\subsection{Selectivity of the assay}

The use of target specific antibody in biosensor as recognition element increases the selectivity of the assay. To investigate the assay specificity, we incubated equal quantity (50 $\mathrm{ng}$ ) of methylated (Jurkat) and unmethylated (WGA) DNA on SPGE electrodes surface and measured the $\mathrm{CC}$ response for both samples in the presence of $5 \mathrm{mC}-\mathrm{GO}_{\mathrm{x}}$ antibody. Fig. 3(a) shows a significant difference (more than 6 times) in charge density between two samples (Jurkat is 246 $\mu \mathrm{C} / \mathrm{cm}^{2}$ and WGA $37 \mu \mathrm{C} / \mathrm{cm}^{2}$ Fig. 3(b)). For further verification, we also carried out two additional sets of experiment where only PBS was used instead of target DNA (referred as NoT) and a positive sample without $5 \mathrm{mC}-\mathrm{GO}_{\mathrm{x}}$ antibody (referred as control). Both the NoT and control showed negligible responses in electrochemical measurements $\left(17 \mu \mathrm{C} / \mathrm{cm}^{2} \mathrm{Vs} 18\right.$ $\mu \mathrm{C} / \mathrm{cm}^{2}$ ). The control studies demonstrate that the assay response is very much dependent on the presence of methylation present in the sample. Altogether the response from controls and synthetic samples clearly demonstrates excellent level of specificity of our assay toward the detection of DNA methylation with negligible background response. 


\subsection{Sensitivity of the Assay}

As samples collected from patients with cancer usually contain a mixture of methylated and unmethylated DNA, it is therefore important to detect the degree of methylation in a high background of unmethylated DNA samples. To evaluate our assay performance for detecting heterogeneous DNA methylation pattern, we measured CC responses for samples with various degree of methylation. The samples were prepared by mixing Jurkat (100\% methylated) and WGA ( $0 \%$ methylated) DNA to get $0 \%$ to $100 \%$ methylated samples. Under the optimum experimental conditions, the $\mathrm{CC}$ responses for various methylation levels show a linear relationship between the charge density and the methylation percentage (Fig. 4, charge density for each percentage was calculated by subtracting the control value from that of the sample value). The calibration plots in Fig. 4(b)(inset) showed good linearity from 5\% to $100 \%$ of methylation with a correlation coefficient, $r^{2}$ of $0.963(n=3)$. From the charge density values, the limit of detection (LOD) was estimated to be as low as 5\% of methylation which was easily distinguishable from the control or $0 \%$ of methylation (i.e. control Vs $5 \%$ was $18 \mu \mathrm{C} / \mathrm{cm}^{2} \mathrm{Vs}$ $57 \mu \mathrm{C} / \mathrm{cm}^{2}$ ). A relative standard deviation (\% RSD) for three independent measurements were calculated to be $<5.0 \%$, suggesting the good reproducibility of assay toward the qualitication of heterogeneous DNA methylation pattern.

The sensitivity (5\% methylation), reproducibility $(<5.0 \% \mathrm{RSD})$, input DNA amount (50 $\mathrm{ng}$ ), and time $(1 \mathrm{~h})$ required for our assay is highly comparable with the recently published DNA analysis methods (Bhattacharjee et al. 2018b; Haque et al. 2017a; Wee et al. 2015). For example, Wee et al. have demonstrated that $5 \%$ of methylation can be detected from $50 \mathrm{ng}$ of DNA input within $2 \mathrm{~h}$ of assay time (Wee et al., 2015). Recently, Povedano and collegues have reported a sandwich type assay for detecting global and regional DNA methylation pattens within $1 \mathrm{~h}$ (Povedano et al. 2018). In this work, for detecting global DNA methylation, a sandwich immunosensor involving the use of two different antibodies was fabricated. Anti- 
$5 \mathrm{mC}$ was first immobilized on the surface of carboxylic acid-modified magnetic beads which capture ss-DNA sequence bearing 5-mC marks. A second antibody conjugated with HRP was then used to recognize any ss-DNA as well to produce electrochemical signal. In contrast, our method is based on the direct adsorption of target DNA onto a bare gold electrode. The adsorption of ss-DNA target onto the bare gold electrode follows the gold-DNA affinity interaction (Koo et al., 2015). The use of the direct adsorption of target DNA samples on a bare gold electrode/surface rather than the conventional approach of using recognition and transduction layers in DNA biosensors is substantially important and novel, as it significantly simplifies the method by avoiding the complicated chemistries underlying each step of the sensor fabrication. Additionally, in our method, an electrochemical-enzymatic redox cycling reaction was used for the first time to achieve global DNA methylation analysis.

\subsection{Analytical application in Cell line samples}

To verify the applicability of our assay in analysing complex biological samples, we examined DNA samples derived from two ovarian cancer (SKOV 3 and OVCAR 3) and one normal cell lines (MeT-5A) (Fig. 5). First, DNA was extracted and purified from these cell lines. Fully methylated ( $100 \%$ methylation) Jurkat and fully unmethylated ( $0 \%$ methylation) WGA DNA were used as internal controls. As expected, both the cell lines (charge density for SKOV 3 and OVCAR 3 was about 177 and $146 \mu \mathrm{C} / \mathrm{cm}^{2}$ respectively) showed relatively higher $\mathrm{CC}$ response compared to that of fully unmethylated WGA $\left(18 \mu \mathrm{C} / \mathrm{cm}^{2}\right)$ sample. As expected these responses were much lower compared to that of fully methylated Jurkat DNA $\left(227 \mu \mathrm{C} / \mathrm{cm}^{2}\right)$ (Fig. 5A). These variations suggest the present of the different level of methylation pattern in these cell lines. Furthermore, the charge density (Fig. 5B) derived from these cell lines are easily detectable compare to those of the control Jurkat and WGA samples. These findings 
suggest that the methylation level of normal cell line MeT-5A $\left(67 \mu \mathrm{C} / \mathrm{cm}^{2}\right)$ is much lower (about 18\%) than that of the other two cancer cell line (SKOV 3 and OVCAR 3). The level of $\mathrm{CC}$ responses also indicate that the methylation patterns in both cancer cell lines (SKOV 3 and OVCAR 3) could exhibit more than $75 \%$ of methylation (by comparing the data shown in Fig 4(B) and Fig 5). A similar level of methylation patterns was also observed for these cell lines in other published work (Tomar et al. 2016).

\section{Conclusions}

In conclusion, we have developed a sensitive and selective biosensor for the detection of global DNA methylation. We took the advantages of $5 \mathrm{mC}$ antibody for selective binding to the $5 \mathrm{mC}$ site and $\mathrm{GO}_{\mathrm{x}}$ enzyme to enhance the sensitivity via enzymatic redox cycling reaction. The assay also avoids the use of bisulfite treatment or PCR amplification steps. It uses the direct adsorption of target DNA samples on a bare gold electrode rather than the conventional approach of using recognition and transduction layers in hybridization based DNA biosensors, which makes it relatively simpler in compare with the conventional hybridization based methylation assays. Under the optimal conditions, this biosensor exhibited high sensitivity (5\% of DNA methylation) with the $\% \mathrm{RSD}$ of $<5 \%$ (for $n=3$ ) for the analysis of heterogeneous DNA samples derived from ovarian cancer cell lines. We believe that the method is not just limited to ovarian cancer DNA, but can easily be extended towards detection of global DNA methylation in samples collected from a diverse range of cancer types. In addition to this, we predict that our electrochemical method could have broad applications in the field of epigenetic research and with further improvements, can potentially find its relevance as a low cost, easy to operation and portable diagnostic tool during cancer diagnosis and treatment. 


\section{Acknowledgements}

This work was supported by the NHMRC CDF (APP1088966 to M.J.A.S.) and higher degree research scholarships (GUIPRS and GUPRS scholarships to R.B.,) from the Griffith University.

\section{Appendix A. Supplementary data (ESI)}

Supplementary data associated with this article can be found, in the online version, at http://dx.doi.org/. 


\section{References}

Akanda, M.R., Choe, Y.-L., Yang, H., 2012. Anal. Chem. 84(2), 1049-1055.

Akanda, M.R., Ju, H., 2017. Anal. Chem. 89(24), 13480-13486.

Bard A.J., Faulkner L.R., 2001. Electrochemical Methods: Fundamentals and Applications, 2nd ed. John Wiley \& Sons.

Bhattacharjee, R., Moriam, S., Umer, M., Nguyen, N.-T., Shiddiky, M.J.A., 2018a. Analyst. DOI:10.1039/C8AN01348A.

Bhattacharjee, R., Tanaka, S., Moriam, S., Masud, M.K., Lin, J., Alshehri, S.M., Ahamad, T., Salunkhe, R.R., Nguyen, N.-T., Yamauchi, Y., Hossain, M.S.A., Shiddiky, M.J.A., 2018b. J. Mater. Chem. B. 6, 4783-4791.

Chen, D., Wang, G., Li, J., 2007. J. Phys. Chem. C 111(6), 2351-2367.

Chen, P., McCreery, R.L., 1996. Anal. Chem. 68(22), 3958-3965.

Dai, Z., Hu, X., Wu, H., Zou, X., 2012. Chem. Commun. 48(12), 1769-1771.

Daneshpour, M., Moradi, L.S., Izadi, P., Omidfar, K., 2016. Biosens. Bioelectron. 77, 1095-1103.

delle Noci, S., Frasconi, M., Favero, G., Tosi, M., Ferri, T., Mazzei, F., 2008. Electroanalysis 20(2), 163-169.

Drummond, T.G., Hill, M.G., Barton, J.K., 2003. Nat. Biotechnol. 21(10), 1192-1199.

Ehrlich, M., 2002. Oncogene 21(35), 5400-5413.

Genereux, D.P., Johnson, W.C., Burden, A.F., Stöger, R., Laird, C.D., 2008. Nucleic Acids Res. 36(22), e150.

Gorski, L.C.W., 2001. Anal. Chem. 73, 2862-2868.

Grunau, C., Clark, S.J., Rosenthal, A., 2001. Nucleic Acids Res. 29(13), E65-65.

Haque, M.H., Bhattacharjee, R., Islam, M.N., Gopalan, V., Nguyen, N.-T., Lam, A.K., Shiddiky, M.J.A., 2017a. Analyst 142(11), 1900-1908.

Haque, M.H., Gopalan, V., Islam, M.N., Masud, M.K., Bhattacharjee, R., Hossain, M.S.A., Nguyen, N.-T., Lam, A.K., Shiddiky, M.J.A., 2017b. Anal. Chem. Acta 976, 84-93.

Hossain, T., Mahmudunnabi, G., Masud, M.K., Islam, M.N., Ooi, L., Konstantinov, K., Hossain, M.S.A., Martinac, B., Alici, G., Nguyen, N.-T., Shiddiky, M.J.A., 2017. Biosens. Bioelectron. 94, 63-73. 
Kaatz, M., Schulze, H., Ciani, I., Lisdat, F., Mount, A.R., Bachmann, T.T., 2012. Analyst 137(1), 5963.

Koo, K.M., Sina, A.A.I., Carrascosa, L.G., Shiddiky, M.J.A., Trau, M., 2015. Anal. Methods 7(17), 7042-7054.

Krejcova, L., Richtera, L., Hynek, D., Labuda, J., Adam, V., 2017. Biosens. Bioelectron. 97, 384-399.

Kurdyukov, S., Bullock, M., 2016. Biology 5(1), 3.

Kurinomaru, T., Kurita, R., 2017. Anal. Methods 9(10), 1537-1549.

Labib, M., Sargent, E.H., Kelley, S.O., 2016. Chem. Rev. 116(16), 9001-9090.

Lai, G., Yan, F., Ju, H., 2009. Anal. Chem. 81(23), 9730-9736.

Lehninger, A.L.N., D. L.; Cox, M. M., 2005. Lehninger Principles of Biochemistry. W. H. Freeman and Company.

Li, L.C., 2007. Designing PCR primer for DNA methylation mapping. Methods in molecular biology (Clifton, N.J.), pp. 371-384, 2007/10/24 ed.

Luo, S., Preuss, D., 2003. Proc. Natl. Acad. Sci U S A 100(19), 11133-11138.

Masud, M.K., Yadav, S., Islam, M.N., Nguyen, N.-T., Salomon, C., Kline, R., Alamri, H.R., Alothman, Z.A., Yamauchi, Y., Hossain, M.S.A., Shiddiky, M.J.A., 2017. Anal. Chem. 89(20), 1100511013.

Paul, C.L., Clark, S.J., 1996. Biotechniques 21(1), 126-133.

Portela, A., Esteller, M., 2010. Nat. Biotechnol. 28(10), 1057-1068.

Povedano, E., Vargas, E., Montiel, V.R., Torrente-Rodriguez, R.M., Pedrero, M., Barderas, R., Segundo-Acosta, P.S., Pelaez-Garcia, A., Mendiola, M., Hardisson, D., Campuzano, S., Pingarron, J.M., 2018. Sci. Rep. 8(1), 6418.

Rein, T., Zorbas, H., DePamphilis, M.L., 1997. Mol. Cell Biol. 17(1), 416-426.

Shiddiky, M.J.A., Torriero, A.A.J., Zeng, Z., Spiccia, L., Bond, A.M., 2010. J. Am. Chem. Soc. 132(29), 10053-10063.

Sina, A.A., Howell, S., Carrascosa, L.G., Rauf, S., Shiddiky, M.J.A., Trau, M., 2014. Chem. Commun. 50(86), 13153-13156.

S Singh, A., Park, S., Yang, H., 2013. Anal. Chem. 85(10), 4863-4868.

Tanaka, S., Kaneti, Y.V., Bhattacharjee, R., Islam, M.N., Nakahata, R., Abdullah, N., Yusa, S.I., Nguyen, N.-T., Shiddiky, M.J.A., Yamauchi, Y., Hossain, M.S.A., 2018. ACS Appl. Mater. Interfaces 10(1), 1039-1049. 
Tanimoto, S., Ichimura, A., 2013. J. Chem. Educ. 90(6), 778-781.

Thomassin, H., Oakeley, E.J., Grange, T., 1999. Methods 19(3), 465-475.

Tomar, T., de Jong, S., Alkema, N.G., Hoekman, R.L., Meersma, G.J., Klip, H.G., van der Zee, A.G., Wisman, G.B., 2016. Genome Med. 8(1), 107.

Tost, J., Gut, I.G., 2007. Methods Mol. Biol. 373, 89-102.

Wang, G.L., Zhou, L.Y., Luo, H.Q., Li, N.B., 2013. Anal. Chim. Acta. 768, 76-81.

Warnecke, P.M., Stirzaker, C., Melki, J.R., Millar, D.S., Paul, C.L., Clark, S.J., 1997. Nucleic Acids Res. 25(21), 4422-4426.

Wee, E.J., Ngo, T.H., Trau, M., 2015. Clin. Epigenetics 7, 65.

Wojdacz, T.K., Borgbo, T., Hansen, L.L., 2014. Epigenetics 4(4), 231-234.

Wojdacz, T.K., Dobrovic, A., 2007. Nucleic Acids Res. 35(6), e41.

Worm, J., Aggerholm, A., Guldberg, P., 2001. Clin. Chem. 47(7), 1183-1189.

Wu, X., Zhang, Y., 2017. Nat. Rev. Genet. 18(9), 517-534.

Yin, H., Sun, B., Zhou, Y., Wang, M., Xu, Z., Fu, Z., Ai, S., 2014. Biosens. Bioelectron. 51, 103-108.

Yu, Y., Wu, T., Johnson-Buck, A., Li, L., Su, X., 2016a. Biosens. Bioelectron. 82, 248-254.

Yu, Y., Zhang, Q., Buscaglia, J., Chang, C.-C., Liu, Y., Yang, Z., Guo, Y., Wang, Y., Levon, K., Rafailovich, M., 2016b. Analyst 141(14), 4424-4431.

Yu, Y., Zhang, Q., Chang, C.-C., Liu, Y., Yang, Z., Guo, Y., Wang, Y., Galanakis, D.K., Levon, K., Rafailovich, M., 2016c. Analyst 141(19), 5607-5617.

Zhang, H., Zhao, Q., Li, X.F., Le, X.C., 2007. Analyst 132(8), 724-737.

Zhang, L., Xu, Y.Z., Xiao, X.F., Chen, J., Zhou, X.Q., Zhu, W.Y., Dai, Z., Zou, X.Y., 2015. Trac-Trend Anal. Chem. 72, 114-122.

Zhang, X., Zeng, Y., Zheng, A., Cai, Z., Huang, A., Zeng, J., Liu, X., Liu, J., 2017. Microchimica Acta 184(7), 1933-1940. 


\section{Figure captions}

Fig. 1. Schematic representation of the assay to detect global DNA methylation. Initially, cell lines were grown and extracted using commercial kit. Then, denatured ssDNA was adsorbed onto a SPGE surface followed by immunorecognition of methylated DNA using the $\mathrm{GO}_{\mathrm{x}}-5 \mathrm{mC}$ antibody. Subsequent detection of the genomic DNA methylation pattern was performed through enzymatic redox cyclic reaction.

Fig. 2. Steady-state kinetic analyses using the Michaelis-Menten model (main) and Lineweaver-Burk model (inset) for the $\mathrm{GO}_{\mathrm{x}}$ by varying the concentrations of (A) Glucose $(0.01-5 \mathrm{mM})$ and $(\mathrm{B})$ Ruthenium complex $(0.01-100.0 \mu \mathrm{M})$ with fixed amounts of $(\mathrm{A}) \mathrm{RuHe}_{\mathrm{x}}$ $(10 \mu \mathrm{M})$ and $(\mathrm{B})$ glucose $(2 \mathrm{mM})$, respectively.

Fig. 3. Selectivity of the designed assay. Comparison of the chronocoulometric response obtained with the immunosensor from no target sample (purple color), control (blue color), WGA (green color) and Jurkat DNA (red color) in (A) and (B) shows their corresponding current density.

Fig. 4. Standard calibration plot for different DNA methylation level from synthetic DNA. (A) represent the charge response for $0 \%$ to $100 \%$ methylation prepared by mixing different ratio of Jurkat and WGA DNA and (B) shows the charge density changes with the methylation level. Error bars estimated as triple of the standard deviation of three independent experiments.

Fig. 5. Analysis of ovarian cancer cell lines and normal cell line. (A) chronocoulometrics response for different cell line and (B) represent charge density comparison between different cell lines. 


\section{Figures}

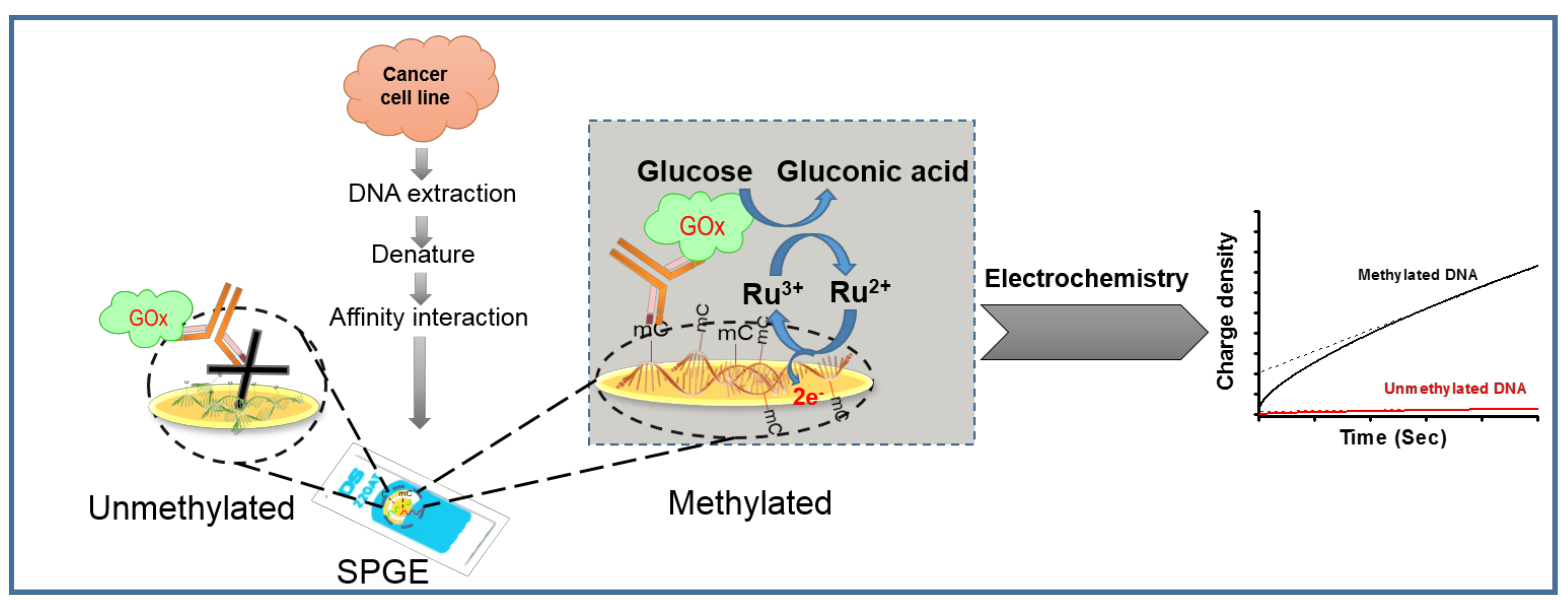

Fig. 1. 
(A)

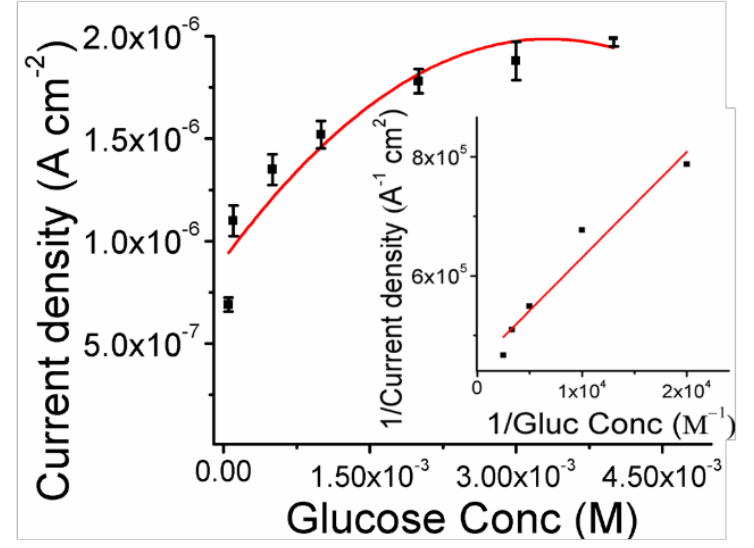

(B)

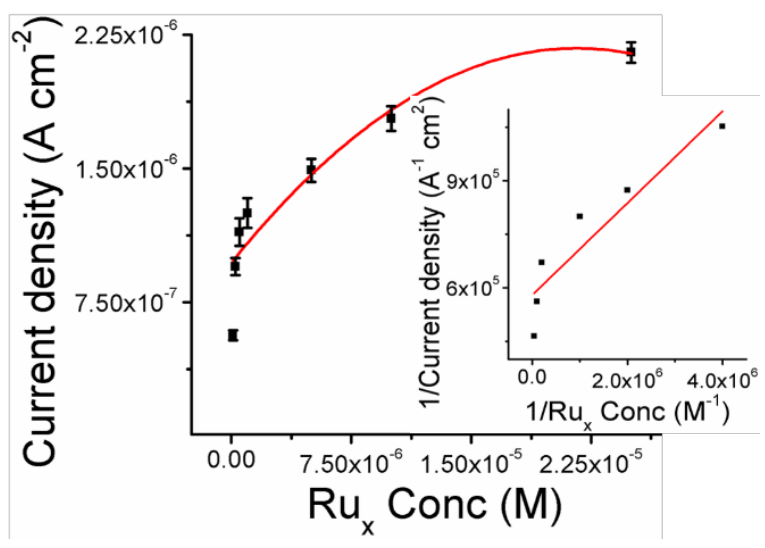

Fig. 2. 
(A)

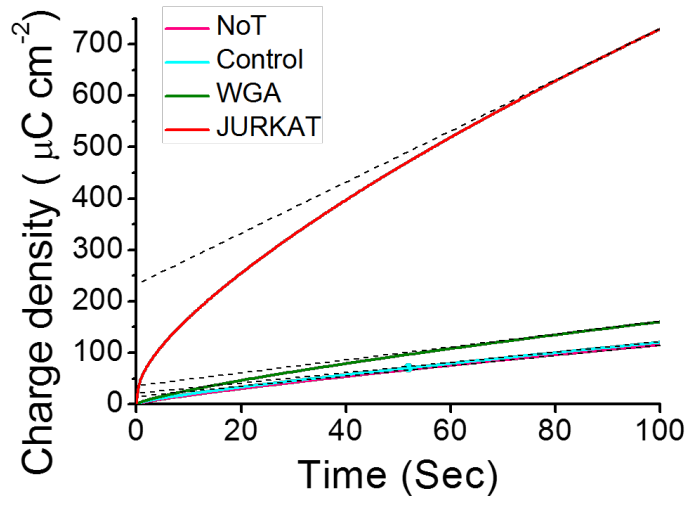

(B)

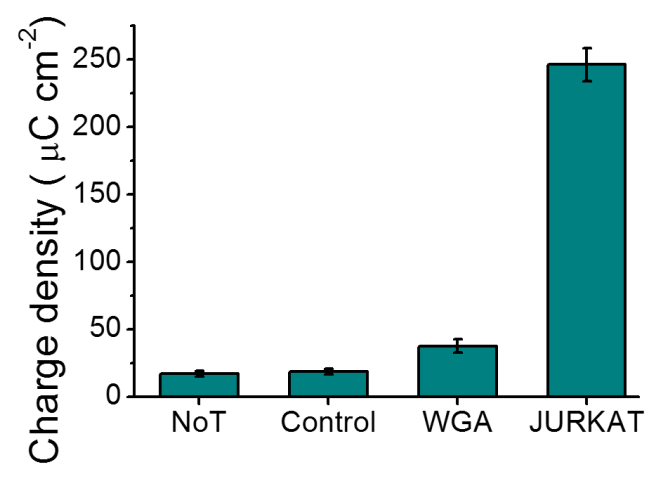

Fig. 3. 
(A)

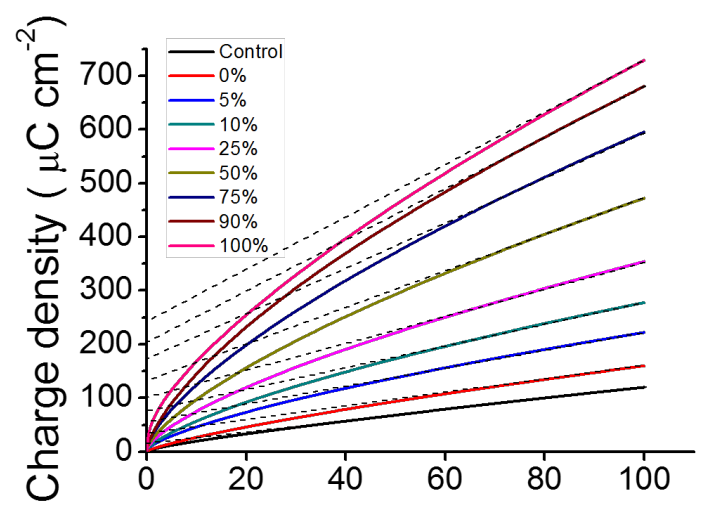

(B)

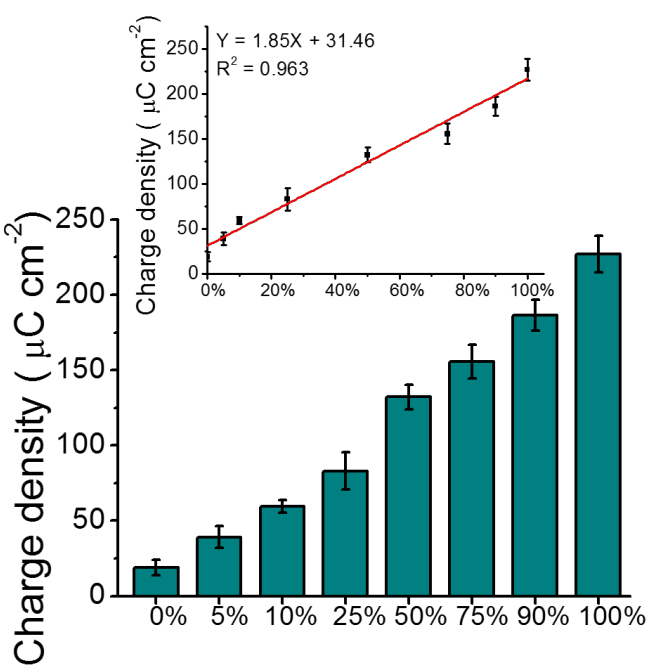

Fig. 4. 
(A)

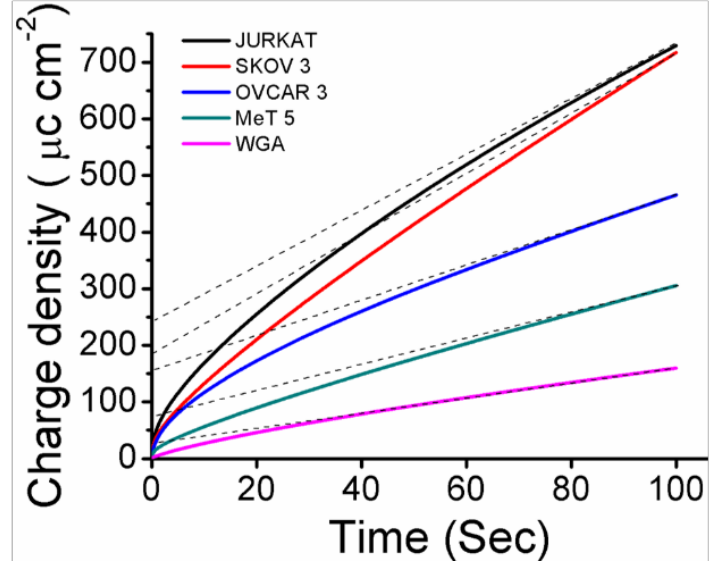

(B)

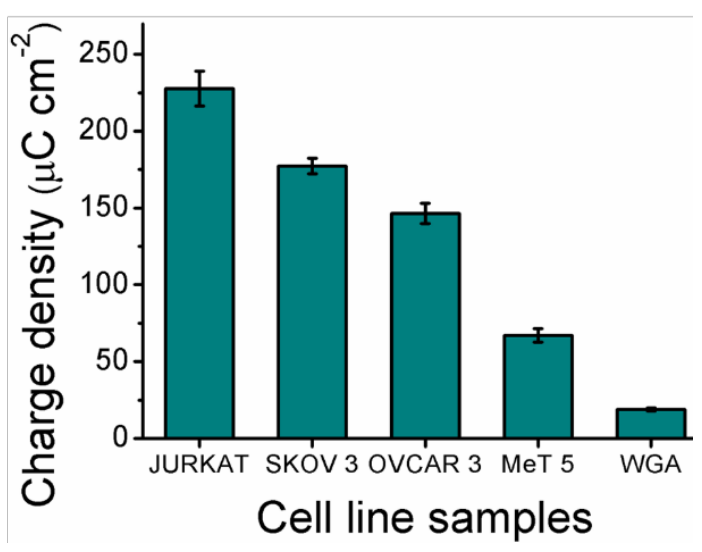

Fig. 5. 


\section{TOC Text}

An electrochemical-enzymatic redox cycling reaction was used for the first time to achieve sensitive and selective detection of global DNA methylation.

\section{TOC Graphic}

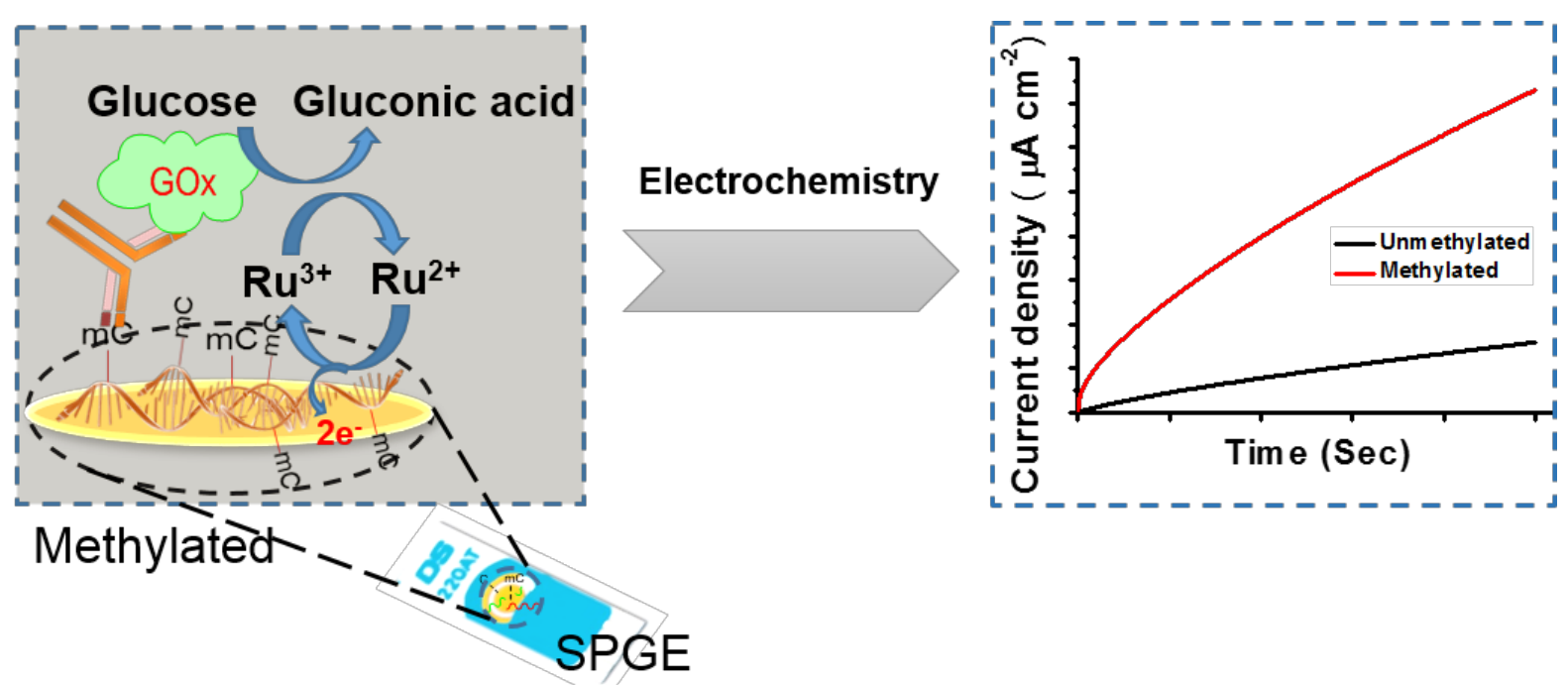

